Madaras Lászlóné

\title{
Az absztrakt szépségü matematikai tételek megoldásának szenvedélyes keresésétől a számítógép tudomány megalapozásáig vezető utak
}

Madaras, Lászlóné: Roads that Lead from Passionate Searching the Solution of Abstract Beauty Mathematical Theorems to the Foundation of Computer Science

The theoretical computer science went through enormous development in the past decades. His results due to the widespread use of computers influence our daily work without the use of it we cannot imagine our life already today. But perhaps few people think that talented Hungarian mathematical generation worked in 20 and 30 years of 20 . Century without whose activity these applications could not have come into exist. In our paper we present the results of Pál Erdös and along with a new generation of mathematical chapter openers, which developed common theory through research and which become since the basis of computer science and information theory.

Keywords: abstract beauty mathematical theorems; particularly beautiful mathematical proofs; an extremely talented Hungarian mathematical generation; discrete mathematics; information theory

\section{ÖsSzEFOGLALó}

Az elmúlt évtizedekben az elméleti számítógéptudomány óriási fejlődésen ment keresztül. Eredményei a számítógépek általános elterjedésének köszönhetően befolyásolják mindennapi munkavégzésünket, alkalmazási lehetőségei nélkül ma már nem is tudjuk elképzelni az életünket.

De talán kevesebben gondolnak arra a tehetséges, munkásságukat a XX. század 20-as, 30-as éveiben megkezdő magyar matematikus generációra, akik tevékenysége nélkül ezek az alkalmazási lehetőségek nem születhettek volna meg.

Dolgozatunkban az Erdős Pál és a vele együtt újabb matematikai fejezeteket nyitó matematikus generáció diszkrét matematika területén elért eredményeit mutatjuk be, melyek a kutatások révén közös elméletté fejlődtek, s melyek azóta a számítógép-tudomány és az információelmélet alapjává váltak.

Kulcsszavak: : absztrakt szépségű matematika tételek, különösen szép matematikai bizonyítá- sok, egy rendkívül tehetséges magyar matematikus generáció, diszkrét matematika; információelmélet

\section{A MATEMATIKA SZEREPE A TUDOMÁNYOKBAN. BEVEZETÉS.}

A 'tiszta' matematika alapvetően 'önmagában' fejlődik, a matematika saját belső fejlődése veti fel a legtöbb problémát és legnagyobb eredményei is többnyire a saját kérdéseire adják meg a választ.

A matematikusok eredményeiket közreadják más tudományok és a gyakorlati élet számára. A matematikai tudás eszközei és a matematika egészéről vallott képek változásai ezért mindig is befolyásolták azokat a kutatási módszereket, amelyeket a különböző tudományterületek fejlődésük folyamán alkalmaztak. A matematika által tanulmányozott egyre absztraktabb mintázatok felismerése, a legmodernebb matematikai eszközök használata hozzájárult a tudományok lényegi vonásainak egyre tökéletesebb megragadásához, s ez által életfeltételeink, 
életkörülményeink javításához.

A matematika a természettudományokat megszületésük óta alkalmazott tudományként szolgálja. Az alkalmazás elsődleges területeként a fizikát tekinthetjük. Galilei szerint: „A természet könyve a matematika nyelvén íródott."

Annak ellenére, hogy a matematika önmagában ugyan nem hivatott a természet rendjének leírására, ismereteinek jó része hosszabb távon mégis 'ráillik' a gyakorlatra. Alig található olyan természettudományos törvény, amelynek a megfogalmazásához ne használnánk fel a matematikát. A különböző egyenletek felálításával kifejezett, azok segítségével leírt összefüggések többnyire a valóságban érvényesülő rendet mutatják be. Persze nem általában a matematika, hanem csak a természettudományokban használt matematikai apparátus az, ami - bizonyos határok között - leírja a természet rendjét.

Ugyanakkor az is igaz, hogy sok esetben a gyakorlati élet veti fel a megoldandó feladatokat a matematikusoknak. A tudományok, fizika, biológia, közgazdaságtan, stb. fejlődése a kezdetektől sok megoldandó problémát hozott felszínre. Ha valamelyik tudománynak igénye merült fel matematikai eszközökre, azt viszonylag rövid idő alatt megoldották a matematikusok. Ez lehet a magyarázata a kutatók egy része azon véleményének, hogy a gyakorlat 'csinálja' a matematikát. Kétségtelenül igaz, hogy az egyes tudományágakban felmerülő igények jelentősen segítették elő tudományunk fejlődését, s hozzájárultak a matematikai eszközök tökéletesítéséhez. A matematikusok egy része valamely tudományág adott problémájára a matematika eszközeivel keresve a megoldást sikeresen bővítette a matematikai ismereteket is.

A természettudományok kialakulásától a 18. századig a tudományos fogalmak lényege a matematika egyszerű kifejezéseivel megadható volt, általában az elemi aritmetika elegendőnek bizonyult a különböző kutatások feladatainak a megoldására. Newton és Leibniz után azonban a matematikát már a számok, a geometriai alakzatok, valamint a mozgás, a változás és a tér tudományának tekintették. Olyan jelenségek leírására is alkalmassá vált, mint pl. a bolygómozgás, a folyadékáramlás, a repülés, az állatok és növények szaporodása, járványok kitörése vagy a nyereség időbeli ingadozása.

A 18. század végére a tudományos ismeretek robbanásszerű fejlődése oda vezetett, hogy a társadalomtudományokban (pl. közgazdaságtan) is kezdték a különböző összefüggéseket, folyamatokat összekapcsolni, önálló, átfogó jellegű elméletté alakítani. Így a természettudományokon kívül a társadalomtudományoknak is egyre inkább szüksége lett a matematikai eszközökre.

A 19. század kezdetétől a 21. század elejéig a matematikában három olyan nagy vonulatot különíthetünk el, amelyek a tudományos elméletek változása szempontjából alapvetőnek bizonyultak.

A 19. század elején a matematika alapját még Eukleidész Elemek és Newton Principia Mathematica c. munkái jelentették. A matematika paradigmáját a geometria adta, egyben ez szolgáltatott mintát a tudományos igazságok felfedezéséhez is. Ennek megfelelően kezdték el a matematikai eszközöket használni a különböző elméletének kidolgozásához. A kor legfejlettebb matematikai eszközei a differenciál- és integrálszámítás voltak.

A változás a matematikai kép fejlődésében a matematika igazságainak az átértelmezésekor következett be. Időben a 19. század második harmadában jelent meg és az új geometriák megjelenéséhez köthető. Ez egy új képét jelentette a matematikának, hiszen bebizonyosodott, hogy egy időben többféle geometriának is lehet létjogosultsága. A köznapi szemlélettől való elszakadással a matematikusok számára újfajta tereket leíró geometriák kidolgozása, s ezzel együtt a lehetőségek tárházának jelentős kibővítése vált lehetővé. A különböző algebrák felfedezése az absztrakt algebra kialakulásához, a szemléletre való támaszkodás elvesztése az analízis aritmetizálásához vezetett. A 19. század végén Georg Cantor lefektette a matematika minden addigi területét megalapozó halmazelmélet alapjait.

A 20. század elején a fizikai világkép alapvető megváltozása, a halmazelmélet ellentmon- 
dásainak megjelenése -, amit George Cantor végtelenről alkotott új eszméi tettek nyilvánvalóvá -, valamint az aritmetika és logika paradoxonjaira válaszként megjelenő Frege és Peano logicizmusa a matematikai tudáskép változásához vezettek. A matematikai szigorúság, igazság, a formalizálás, illetve bizonyítás fogalmai ismét változni kezdtek, ahogyan a matematikai alapokban problémák mutatkoztak. Az 1930-as évektől a francia matematikusok egy csoportja kezdte újraírni a matematikát (Weintraub, Mirowski). A szigorú matematika nem alapult többé a körülöttünk levő világ fizikai modelljére, inkább a matematikára önmagára.

\section{A DISZKÉT STRUKTÚRÁK VIZSGÁLATÁNAK ELŐTÉRBE KERÜLÉSE}

A 20. század első harmadát követően a különböző tudományterületek kutatási eredményeit az analízis hagyományos eszközei már nem igazán tudták segíteni. A természet- és társadalomtudományokban is felmerült és egyben előtérbe is került a diszkrét struktúrák vizsgálatának fontossága.

A század eleji kvantumfizika a fizikai jelenségek diszkontinuitását állítja, a mozgás kontinuitása a mikrovilágban csak feltételezés lehetett. A kvantummechanika értelmezésénél a mérési eredményeket a klasszikus fizika fogalmaival már nem írhatják le, mert a kvantumelmélet fogalmi rendszere alapvetően tért el a klasszikus fizikai koncepciótól. Ezért a kvantumfizikában az elemi részecskék tanulmányozásához a diszkontinuitást leíró matematikai eszközök váltak szükségessé.

Az újabb matematikai eszközök segítségét igényelték a biológia azon kísérletei, melyekben a genetikai kód véges struktúráját igyekeztek megfejteni. A biológusok keresni kezdték azokat a molekulákat, amelyekben az élőlények tulajdonságai vannak kódolva. Ezzel új dimenzió jelent meg a biológiai gondolkodásban: az élőlény megjelenési formája, tulajdonságai mögötti rejtett háttértényezők, az élőlényt leíró 'tervrajz' jellegének a vizsgálata.

Hasonlóan a közgazdaságtanban is -, amely ekkorra már egyre komolyabb alkalmazójává vált a matematikának - problémaként jelentkezett, hogy a véges sok elemre, vagy folyamatra vonatkozó kérdéseik nagy részét már nem tudták a hagyományos matematika eszköztárával megoldani.

A közgazdaságtani problémák megoldásához kezdetekben ún. lineáris, determinisztikus modelleket állítottak fel. Ezek a modellek feltételezték, hogy: „A matematikai programozás hivatása az, hogy (...) olyan számításokat végezzen, amelyek bizonyos fokig ellenőrzik a gazdaságpolitikai feladatokat is, s támpontokat nyújtsanak esetleges módosításukhoz." [Kornai] Megoldásuk sikere azon a feltevésen alapult, hogy a termelési folyamatok korlátlanul oszthatók és konvex függvényekkel leírhatók. Ha azonban figyelembe kívánták venni az oszthatatlanságot, ehhez már új matematikai eszközöket kellett találni, melyek azután a diszkrét programozáshoz illetve más kombinatorikus optimalizációs modellekhez vezettek.

\section{AZ ÚJABB MATEMATIKAI FEJEZETEKET NYITÓ MAGYAR MATEMATIKUS GENERÁCIÓ}

A fentiek alapján a matematikában is a folytonosság tulajdonságait vizsgáló analízis helyett a diszkrét mennyiségekkel, azok összekapcsolódásával és kölcsönhatásával foglalkozó kutatások kerültek előtérbe, és a korábbi elméletalkotó megközelítés helyét átvette a problémamegoldó eljárások keresése. Ezért az újonnan matematikussá váló nemzedék részére a különböző fiatalkori matematika versenyen szerzett feladatmegoldó képesség, rutin igen hasznosnak bizonyult a kutatásokban.

A új felfedezések nagyban köthetők ahhoz a tehetséges magyar matematikus generációhoz, 
amely a 20. század 20-as, 30-as éveiben kezdte meg munkásságát. A Hajós György, Turán Pál, Szőkefalvi-Nagy Béla és Erdős Pál nevével fémjelezhető generáció meghatározó eredményeket ért el a matematika újabb fejezeteinek kutatásában. Ez a Fejér Lipót és Riesz Frigyes utáni matematikus-generáció kiemelkedő kutatói és nevelői munkásságával alakította a következő generációk kutatási irányát, s meghatározta a magyar matematika arcát. Hatásuk rendkívül széleskörűvé vált külföldön is, munkásságukkal egészen az 1970-es évek végéig sikerült fenntartani a magyar matematika nemzetközi vezető szerepét. Világraszóló eredményeiket tehetségük mellett elősegítette, hogy már középiskolás koruktól ösztönözve voltak kimagasló matematikai eredmények felmutatására. A havonta megjelenő Középiskolai Matematikai Lapok (Kömal) c. folyóiratnak rendszeresen küldték be a kiirt feladatok megoldásait és neveiket ott találhatjuk az országos tanulóversenyek (Eötvös-verseny 1921-től, OKTV 1923-tól) legeredményesebb résztvevői között. Az egyetemeken pedig olyan nemzetközi eredményeket elért professzorok oktatták őket, mint Fejér Lipót és Suták József, Kürschák József, Kőnig Dénes, Riesz Frigyes és Haar Alfréd.

Közülük Hajós György (1912.02.21.-1972 .03.17) világhírű geométer, akinek kiemelkedő eredményei voltak a diszkrét geometriában, a gráfelméletben és a numerikus analízisben. Hajós munkásságával megindította a véges Abel-csoportok klasszikus elméletének modern elméletté való kiépítését. Ezt az elméletet a véges Abel-csoportok Hajós-Rédei-féle faktorizációs elméletnek is szokás nevezni. A műszaki értelmiség számára 1960 óta Hajós György Bevezetés a Geometriába c. könyve jelenti az alapvető irodalmat a geometria megértéséhez és vizsgálataihoz. Tananyagán mérnökök és matematika tanárok nemzedékei nőttek fel (köztük jómagam is), és még ma is használják a felsőoktatásban.
Turán Pál (1910.08.18.-1976.09.26.) érdeklődésének homlokterében a számelmélet állt, publikációinak többsége számelmélettel, különösen a prímszámok elméletével kapcsolatos. Legjelentősebb felfedezése az ún. hatványösszeg-módszer megalkotása, amelyet ma is világszerte, mint Turán-féle módszert ismernek. Új utat talált a prímszámelmélet nagy és addig megoldatlan problémáihoz, ill. számos tételt bizonyított, amelyek más, addig ismert módszerrel nem voltak megközelíthetőek. Nemzetközileg is kiemelkedően új eredményeket ért el az ún. kvázi analitikus függvények, a trigonometrikus és majdnem-periodikus polinomok értékkészlet-eloszlásának vizsgálata terén. Tőle származik a funkcionális algebra (algebrai egyenletek analitikus elmélete) kutatási irányzat elindítása és a gráfelméleti szélsőérték fogalma. Gráf tétele indította el az extremális gráfelméletet. Nevéhez füződik továbbá az összehasonlító prímszámelmélet kiépítése, ill. jelentős szerepet játszott a valószínűségi számelmélet megszületésében. Érdekes eredményekre jutott algebrai egyenletek megoldásával kapcsolatban is.

Egykori tanárom, Szőkefalvi-Nagy Béla (1913.07.29-1998.12.21.) tudományos tevékenységének súlypontja a funkcionálanalízis, operátorelmélet, valamint a valós és komplex függvénytan területe volt. A huszadik századi matematika egyik legfontosabb ágát, a funkcionálanalízist művelte, mely döntő szerepet játszott a modern fizika, a kvantummechanika matematikai leírásához nélkülözhetetlen elmélet alapjainak kidolgozásában. A matematikának ez az ága szoros kapcsolatban állt az elméleti fizikával, s azon belül is a kvantummechanikával, hiszen Neumann János zseniális meglátásának eredményeképpen az egyes fizikai mennyiségek megfeleltethetők a Hilbert-tér egy-egy lineáris operátorának. Így az ilyen operátorok elmélete joggal került a kvantummechanika matematikai apparátusának középpontjába. 
Az új matematikai területek kidolgozásának legfőbb motorja a Wolf-díjas Erdős Pál (1913. 03.26.-1996.09.20.) volt. A diszkrét matematika jelenlegi fejlettsége döntően az ő érdeme.

Kiemeljük, hogy 2013.07.03-tól egyhetes akadémiai konferencián emlékeztek meg a 100 éve született Erdős Pál munkásságáról. A konferencia 150 meghívott előadót és további ötszázötven érdeklődő matematikust vonzott a világ minden részéről Budapestre.

Munkásságát és néhány főbb eredményét a kortárs matematikus generáció eredményeiben betöltött különlegesnek mondható jelentősége, későbbi hatása miatt mi is részletesebben méltatjuk.

\section{ERDŐS PÁL SZEREPE A VILÁGHíRŰVÉ VÁLT MAGYAR MATEMATIKAI ISKOLÁBAN'}

\section{„Bölcs agya nyitva áll minden problémára, Ezreseket érő sejtéseinek se szeri, se száma. De hát Pali bácsi kérdései ritkán fizetnek. Hogy mennyire nehezek, Tessék megpróbálni bármelyiket."}

(Allen J. Schwenk: Szegény Jó öreg. Ford.: Lehel Jenő)

A kivételes tehetségű, igen széles látókörű matematikus óriási hatást gyakorolt a 20. század matematikájára. Mind a matematika fejlődésében, mind pedig a népszerűsítésében betöltött szerepe egyedülállónak mondható. A világ eddigi egyik legtermékenyebb matematikusa volt, hiszen neves matematikai lapokban közölt publikációinak száma elérte az ezerötszázat.

A matematika szinte minden területét gazdagította. Megjelent munkái a számelmélet, a valószínúségszámítás és ergodelmélet, a gráfelmélet és aszimptotikus kombinatorika, a konstruktív függvénytan, a halmazelmélet és halmazelméleti topológia, a sorelmélet, a komplex függvénytan és a diszkrét geometria területeire összpontosulnak. „Gyakorlatilag o teremtette meg a valószínűségi számelmélet, a végtelen számosságok partíció-kalkulusát, az extremális gráfok és a végtelen gráfok elméletét." [Bollobás]

Kezdeti sikereit a számelmélet területén érte el. Már 10 éves kora óta érdekelték a prímszámok, amikor édesapja elmondta annak a bizonyítását, hogy végtelen sok prímszám van. Tizennyolc éves volt, amikor bebizonyította a Bertrand-sejtést, miszerint egy pozitív egész szám és kétszerese között mindig található prímszám. A sejtést először Csebisev bizonyította 1850-ben (5 évvel Bertrand kijelentése után), de igen bonyolult módon. Egy évvel később logaritmikus alsó korlátot is tudott adni szomszédos prímszámok különbségére. 1933ban bebizonyította, hogy végtelen sok $n$-re

$p_{n+1}-p_{n}>c \log n \log \log n /(\log \log \log n)^{2}$

A Pázmány Péter Egyetem hallgatójaként szakmai múhelyeket szervezve újabb és újabb matematikai problémákat vetett fel a számelmélet, halmazok, gráfok, az analízis és a matematika legkülönfélébb területeiről ösztönözve ezzel hallgatótársai problémamegoldását. 1934-ben 21 évesen, az egyetem elvégzésével egy időben Fejér Lipótnál doktorált, majd négy évre szóló ösztöndíjjal Manchesterbe utazott. 1936ban Turán Pállal közösen fogalmazta meg azt a sejtést, hogy az egész számok bármely pozitiv sürúségű sorozata tartalmaz akármilyen hosszú számtani sorozatot.

Erdős a harmincas évek végén az USA-ba emigrált, de a háború után sehol sem telepedett le. Világpolgárnak számított, akinek fő bázisa azért Budapest maradt. Személyében talán egy új tudóstípus egy „prototípusa” jelent meg, akit a matematika szenvedélyes kutatásának szentelte és rendelte alá az életét.

1938-1939-ben a princetoni Institute for Avanced Study ösztöndíjasaként kiemelkedő 
dolgozatokat írt Mark Kaccal és Wintner Auréllal, egy alapvető approximációelméleti dolgozatot Turán Pállal és megoldotta Hurewicz egy fontos dimenzióelméleti problémáját.

1949-ben Atle Selberggel együtt sikerült elemi eszközökkel is igazolnia a prímszámtételt, amely a prímszámok végtelenbe nyúló sorozatát jellemzi egy másik sorozat, az $x / \ln x$ segítségével (az x-nél nem nagyobb prímszámok száma aszimptotikusan $x / \ln x$, ha $\left.x^{\circledR} ¥\right)$, amit előzőleg fél évszázadon át lehetetlennek tartottak.

Erdős különösen a kombinatorikában alkotott kiemelkedőt. Sokat foglalkozott a Ramseytípusú problémákkal. Ezek egyik legismertebb speciális esete, hogy bármely $a$ és $b$ pozitiv egész számhoz létezik egy olyan legkisebb $R(a, b)$ csak $a$-tól és $b$-től függő pozitiv egész szám, hogy ha egy $R(a, b)$ pontból álló teljes gráf éleit pirossal és kékkel kiszínezzük, akkor biztosan lesz olyan $a$ pont, amelyek között minden él kék, vagy $b$ olyan pont, amelyek között minden él piros. Az $R(a, a)$ Ramseyszámok meghatározása igen bonyolult feladat. Tudjuk, hogy $R(3,3)=6, R(4,4)=18,43$ $<R(5,5)<49$. Erdős szerint, ha a földön kívüliek a föld elpusztításával fenyegetőzve kérnék, akkor az $R(5,5)$ értékén számítógép segítségével érdemes lenne gondolkodni, de az $R(6,6)$ esetén már nem lenne más választásunk, mint fegyverrel megküzdeni velük.

Erdős felismerte, hogy a véletlen módszerek hatékonyan alkalmazhatók olyan problémák megoldásainál is, amelyek nem a véletlenen alapulnak. Hozzá fűződik a valószínűség-számítási módszerek bevezetése és alkalmazása a matematika egyéb területein.

Erdős maga így nyilatkozott a valószínűség-számítás számelméletben történő alkalmazására vonatkozó egyik Kaccal közösen bizonyított tételükről: „.... talán egyik legjelentősebb eredményem a közös munkánk Kaccal, mely talán az egyik elindítója volt a valószínűség-számítás alkalmazásának a számelméletben és mely remélem a szerzőket századokkal fogja túlélni. [Erdős]. Az Erdős-Kac tétel azt állítja, hogy ha $\omega(n)$ egy n szám egymástól különböző prímtényezőinek száma, akkor a

$$
\frac{\varpi(n)-\log \log n}{\sqrt{\log \log n}}
$$

valószínűség-eloszlás standard normális eloszlást mutat. [A.Granville and K.Soundararajan] A nemalgoritmikus gráfelméletbe is Erdős Pál vezetett be valószínűség-számítási módszert az ötvenes években [Alon and J.Spencer in [1]]. Ennek alapgondolata az volt, hogy sokszor egy bizonyos, speciális tulajdonságokkal rendelkező struktúrát (gráfot, számsorozatot stb.) nem tudunk megkonstruálni, de véletlenszerűen választva egy nagyobb osztályból, a kívánt tulajdonság nagy valószínűséggel teljesülni fog. Ez a fogás mostanra a gráfelmélet alapvető és jól működő eszközévé vált. A valószínűség-számítás olyan tételek bizonyításába került bele, amelyeknek látszólag semmi közük nincs hozzá.

Az 1950-es évek vége felé kezdte kombinatorikus halmazelméleti kutatásainak zömét. A Hajnal Andrással közös dolgozatok közül a leghíresebb a partíciókalkulusról szóló 1965ben írt Erdős-Hajnal-Rado dolgozat (Partition relations for cardinal numbers), ami nagy végtelen halmazok relatív méretének a kifinomult változata. Ugyancsak az 1960-as években kezdett el dolgozni Sárközi Andrással és Szemerédi Endrével sorozatok oszthatósági tulajdonságain. Erdős és Turán fektették le a statisztikus csoportelmélet alapjait. A Surányi Jánossal írt népszerű Válogatott fejezetek a számelméletből (1960) c. könyvében számelméleti eredményeinek egy része is megtalálható. 1966-ban John Selfrige-dzsel belátta, hogy egymásutáni számok szorzata sohasem teljes hatvány, s ezzel a számelmélet egy évszázados problémáját oldották meg. Rényi Alfréddel közösen alapozták meg a véletlen gráfok elméletét. 
Erdős honosította meg az együttmúködő matematikát. Ennek a lényege az volt, hogy több kutató egyidőben közösen gondolkodott ugyanazon a problémán, és erőfeszítéseik, együttműködésük révén kimagasló eredmények születtek. Ő maga közel ötszáz szakcikknek volt a társszerzője. Ez utóbbira találták ki a matematikusok az Erdős-számot. Ez azt jelentette, hogy 1-es számot kapott, akinek Erdőssel közös publikációja jelent meg, és 2-est a velük ugyanilyen kapcsolatban állók, stb. A számozást később más tudományágakban is alkalmazták. Az informatika a hálózati viszonyok leírásában az elemek közötti távolság leképezésére is felhasználja.

Kedvence volt a sejtések megfogalmazása és a sejtésként élő tételek bizonyítása. Matematikai problémák százait vetette fel. Feltehetőleg több sejtést fogalmazott meg, mint a világon valaha élt összes matematikus összesen. A bizonyításoknál pedig igazi megoldást az egyszerú és szép, lehetőleg az elemi matematikán és a szellemes ötleteken alapuló módszerek alkalmazására épülő gondolatmenet jelentette nála.

\section{5.ÖSSZEFOGLALÁS. A DISZKRÉT MATEMATIKA GYAKORLATI ALKALMAZHATÓSÁGA}

Erdős Pál és a vele együtt újabb matematikai fejezeteket nyitó matematikus generáció valójában csak problémákat talált és oldott meg. Pályájuk kezdetekor még egyáltalán nem látszott, hogy lesz-e, és ha igen milyen gyakorlati alkalmazása ezeknek az új matematikai elméleteknek. Csupán a felmerülő problémák szépsége és nehézsége inspirálta őket a kutatásában. A számos, szinte független probléma végül azonban új elméletté állt össze. Kiderült, hogy a diszkrét matematika eredményeit nagymértékben tudja hasznosítani a számítógép-tudomány. Sőt azt mondhatjuk, hogy a diszkrét matematika a számítógép-tudomány és az információelmélet alapjává vált. Az elektronikus számítás jól megfogalmazott nehéz és fontos matematikai problémák hatalmas tárházát képezi, amelyeket az algoritmusok, adatbázisok, formális nyelvek, a számítógépes biztonsági rendszerek alapjául szolgáló titkosírás, kriptográfia, stb. vetnek fel. Ezek megoldásánál általában kiderül, hogy legtöbbjüknek köze van a diszkrét matematikához, formális logikához és valószínűség-számításhoz. A diszkrét matematika segítségével hatásosan tudjuk megoldani pl. azokat a problémákat, amelyek a különböző algoritmusok, programok esetén leírják azt az eljárást, hogy hogyan lehet a leggyorsabban elvégezni egy-egy adott múveletet. De sok modern gyakorlati számítógépes algoritmus hatékonysága múlik az Erdősék által bevezetett valószínűség-számítási eszközök használatán is. Ezek megmutatják, hogy megfelelő véletlen kiválasztásokkal hogyan kaphatunk meg olyan objektumokat, melyeket explicit módon nehéz lenne megkonstruálni. A számítógépek keresőprogramjainak működése pedig nagyrészt a gráfelméleten alapul.

Áttekintve ezen - alapvetően az elméleti matematikával foglalkozó - kutatók munkásságát nyilvánvalóvá válik, hogy matematikai eredményeik óriási hatást gyakorolnak mindennapi életünkre. Ezért fontosnak tartjuk hangsúlyozni, hogy egy-egy matematikus munkásságát nemcsak önmagában, a saját tudományterületén elért eredményei alapján kell tekinteni. Sok esetben célszerű a matematikus-generációk munkásságát együtt is értékelni, mert láthattuk, hogy együttes produkciójuk néhány év múlva óriási hatással lehet a társadalom egészére.

Az elmúlt évtizedekben elméleti számítógéptudomány óriási fejlődésen ment keresztül. Eredményei és alkalmazási lehetőségei a számítógépek általános elterjedésének köszönhetően befolyásolják mindennapi munkavégzésünket, amelyet ma már nem is tudunk elképzelni ezen alkalmazások nélkül.

Ennek a generációnak és közülük különösen Erdős Pálnak köszönhető, hogy a diszkrét 
matematikát ma a világon többen is magyar tudománynak tartják. Tény, hogy jó néhány magyar matematikus müveli napjainkban is igen eredményesen ezt a területet. Ki kell itt emelnünk a matematika Nobel-díjának számító Abel-díjas (2012. évi) Szemerédi Endrét, aki a Rutgers Egyetem számítógép-tudományi tanszékének egyetemi tanára. Hozzá hasonlóan a világ élvonalába tartozó magyar mate- matikus az Erdőssel már tizennégy évesen közösen publikáló Bollobás Béla, a Cambredge-i Egyetem professzora, Lovász László Kyoto- és Wolf díjas (szintén egykori tanárom), az Eötvös Lóránd Tudományegyetem professzora, Hajnal András, az MTA Matematikai Kutatóintézet kutatója, de folytathatnánk még tovább a sort vagy tucatnyi magyar matematikus felsorolásával.

\section{Felhasznált irodalom}

[1.] N. Alon and J. Spencer 1992: The Probabilistic Method. With an Appendix by Paul Erdõs, Wiley, New York, 1992

[2.] Alpár László 1988: Egy ember, aki a számok világában él. Beszélgetés Erdős Pál akadémikussal. Magyar Tudomány, 1988. 3. pp 213-221.

[3.] Bollobás Béla 1997: Erdős Pál. Természet Világa, 128. évf. 2. sz. 1997. február, p.77.

[4.] Erdős Pál 1997: Hogyan lettem matematikus és világvándor? Természet Világa, 128. évf. 2. sz. 1997. február, pp 78-79.

[5.] Filep László 1997: A tudományok királynője - A matematika fejlődése. Typotex, Budapest, 1997.

[6.] A. Granville and K. Soundararajan 2007: Sieving and the Erdős-Kac Theorem. Equidistribution in Number Theory, An Introduction. NATO Science Series, Volume 237, pp 15-27. Springer, Netherlands, 2007

[7.] Hajnal András 1983: Erdős Pálról 70. születésnapján. Népszabadság, 1983.03.26. pp 102-106.

[8.] Kornai János 1973: A gazdasági szerkezet matematikai tervezése. Közgazdasági és Jogi Könyvkiadó, Budapest, 1973.

[9.] Lovász László 1988 a: Egységes tudomány-e a matematika? Természet Világa, 1988. III. különszám, pp 44-48.

[10.] L. Lovász 1988 b: Algorithmic mathematics: an old aspect with a new emphasis, in: Proc. 6th International Congress on Math. Education, Budapest, 1988, J. Bolyai Math. Soc., 1988, pp 67-78.

[11.] Lovász László 1996: A sejtés múvészete, Erdős Pál emlékére. Népszabadság, 1996.10.18.

[12.] Lovász László 2012: Prímek, számítógépek és Abel-dij. Természet Világa, 143. évfolyam, 6. szám. pp. 242-44.

[13.] H. Reichenbach 1930: Atom és világegyetem. A jelenkor fizikai világképe, Ford.: Náray-Szabó István, Franklin-Társulat, Bp., 1930.

[14.] Simonovits Miklós 1993: Erdős Pál 80. születésnapjára. Polygon, 1993.06. pp 1-5.

[15.] Staar Gyula 1979: Élete a matematika. Tollvonások Erdős Pál arcképéhez. Természet Világa, 1979. 3. sz. pp 102-106.

[16.] Turán Pál 1963: Erdős Pál 50 éves. Matematikai Lapok, 1963. pp 1-28. 